\title{
Experimental Investigation of Energy Transfer in the Inflatable Greenhouse
}

\author{
K. O. KESSEY* and P. G. GLOCKNER** \\ $\left(\begin{array}{c}\text { Department of Mechanical Engineering, } \\ \text { The University of Calgary, Calgary, } \\ \text { Alberta, Canada }\end{array}\right)$
}

\begin{abstract}
A transparent plastic-covered model greenhouse built without vegetation was tested under various operating conditions to determine the relative magnitude of its energy fluxes, namely, hot air heat and solar energy inputs, surface and ground losses as well as its efficiency.

It is established that surface or membrane losses are quite comparable to the energy inputs and even larger than either input under certain operating conditions. The efficiency is found to be generally below $50 \%$ and is particularly low at high solar intensities, dropping to a low of $10 \%$ under such conàitions.

The Reynolds Number and a new Solar Parameter characterizing the mass flow rate of hot air injection and the rate of solar energy transmission into the greenhouse, respectively, are found to have a very significant influence on greenhouse performance. Notably, membrane losses are observed to increase remarkably with either increasing Reynolds Number or rising Solar Parameter.
\end{abstract}

\section{Introduction}

In recent years, the inflatable plastic-covered greenhouse has been gaining increasing attention over the conventional glass-covered greenhouse due to the relatively low cost and ease of construction of the former. However, while a great deal of work has been carried out on the thermal performance of the conventional greenhouse (Woode, 1909; Businger, 1963; Annufrier and Pozin, 1966; Edwards and Lake, 1967; Takakura et al., 1979; Pozin, 1971; Seginer and Levav, 1971; Selcuk, 1970; Iwakiri and Uchijima, 1971; Kimball, 1973; Takami and Uchijima, 1977) research work on the inflatable greenhouse is only beginning (Horiguchi, 1978; Snook and Tarasuk, 1978).

This present study involves energy transfers and is largely motivated by a suggestion of Glockner and Malcolm (1980) regarding the use of waste heat from compressor stations situated along oil pipelines in Alberta, Canada, as the source of heat for the inflatable greenhouse. An appreciation of

Received 10 April, 1982.

* Visiting Professor, ** Professor and Head

Report No. 240 (The University of Calgary) the feasibility of such a scheme obviously requires a knowledge of the various energy fluxes involved, in particular, the energy losses.

\section{Equations}

\subsection{Mathematical Model}

The model is a semi-cylindrical structure with a transparent cover on its circumferential periphery and an insulated base. Ambient air is blown through a heater by means of a blower and is consequently heated before being admitted into the greenhouse which is simultaneously subjected to solar energy input (Fig. 1).

\subsection{Energy Transfers}

As shown in Fig. 1, the greenhouse configuration gains heat from two heat sources, namely, hot air and solar energy and at the same time loses heat to two sinks, the ambient air and the ground. These energy transfers are aided and complicated by mass movement inside and outside the greenhouse. Their heat fluxes are determined under the two assumptions that air behaves like a perfect gas and that its properties such as specific heat and thermal conductivity, remain constant. 


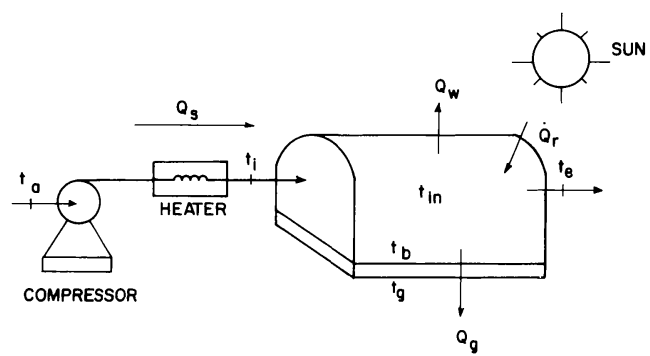

Fig. 1. Schematic diagram showing energy transfers.

\section{Heat Sources:}

Heat supplied to the outside air by all external sources (including the blower and the heater) before entering the greenhouse is given by

$$
\dot{Q}_{s}=\dot{m}_{a} C_{p}\left(t_{i}-t_{a}\right)
$$

The rate of solar energy transmitted into the greenhouse is given by

$$
\dot{Q}_{r}=A_{w} \tau I_{t}
$$

In equation (2), we have used the global intensity of radiation, $I_{t}$, for which data are available. It has been assumed that the transmissivity of the membrane is the same for both the diffuse and the direct/beam components of solar intensity. If separate data were available for the two components, it would have been preferable to treat them independently, following Brinkworth (1972), for example. The simplified approach used here appears to be acceptable for most engineering analyses. Equations (1) and (2) may be rearranged in dimensionless form as

$$
\varepsilon_{s}=\dot{Q}_{s} / L k_{a} T_{o}=(\pi d / 4 L)\left(R N \times P_{r}\right)\left(\mathscr{T}_{i}-\mathscr{J}_{a}\right)
$$

and

$$
\varepsilon_{r}=\dot{Q}_{r} / L k_{a} T_{o}=\pi(1 / 2+D / 4 L) \not
$$

since the peripheral area, $A_{w}$, is given by $(\pi D L / 2$ $\left.+\pi D^{2} / 4\right)$.

\section{Heat Losses:}

The heat losses to the heat sinks, namely the ambient air and the ground, are related primarily to the non-uniform temperatures within and around the greenhouse. In this global analysis, the simplifying assumption is made that both the inside and outside of the greenhouse are at uniform temperatures at any particular instance of time.

Based on an average or uniform base surface temperature, $t_{b}$, the instantaneous heat loss to the ground through the insulation is given by

$$
\dot{Q}_{g}=(D L / l)\left(k_{i}\right)\left(t_{b}-t_{g}\right)
$$

or, in dimensionless form, as

$$
\varepsilon_{g}=\dot{Q}_{g} / k_{a} L T_{o}=\left(D k_{i} / l k_{a}\right)\left(\mathscr{J}_{b}-\mathscr{J}_{g}\right)
$$

The heat loss through the plastic membrane may be obtained by writing an energy balance equation for the greenhouse taking into consideration the steady flow of air into and out of the greenhouse. On the assumption of uniform instantaneous inlet and outlet temperatures, $t_{i}$ and $t_{e}$ respectively, the membrane heat loss is found to be

$$
\dot{Q}_{w}=\dot{Q}_{r}+\dot{m}_{a} C_{p}\left(t_{i}-t_{e}\right)-\dot{Q}_{g}
$$

In dimensionless form, substituting for $\dot{Q}_{r}$ and $\dot{Q}_{g}$ and rearranging, one obtains

$$
\begin{aligned}
\mathcal{E}_{w} & =\pi(1 / 2+D / 4 L) \mathcal{K} \\
& +(\pi d / 4 L)\left(R N \times P_{r}\right)\left(\mathscr{T}_{i}-\mathscr{T}_{e}\right) \\
& -\left(D k_{i} / l k_{a}\right)\left(\mathscr{T}_{b}-\mathscr{T}_{g}\right)
\end{aligned}
$$

\section{Overall Heat Transfer Coefficient:}

Assuming that the interior of the greenhouse is at a uniform temperature, $t_{i n}$, the overall heat transfer coefficient may be obtained as

$$
U=\dot{Q}_{w} / A_{w}\left(t_{i n}-t_{a}\right)
$$

Substituting for $\dot{Q}_{w}$ from equation (7) and rearranging, the dimensionless overall heat transfer coefficient is given by

$$
\begin{aligned}
\mathscr{W} & =U A_{w} / k_{a} L=[\pi(1 / 2+D / 4 L) \mathcal{K} \\
& +(\pi d / 4 L)\left(R N \times P_{r}\right)\left(\mathscr{T}_{i}-\mathscr{T}_{e}\right) \\
& \left.-\left(D k_{i} / l k_{a}\right)\left(\mathscr{T}_{b}-\mathscr{T}_{g}\right)\right] /\left(\mathscr{T}_{i n}-\mathscr{T}_{a}\right)
\end{aligned}
$$

\subsection{Efficiency}

Let us define the thermal efficiency of the greenhouse as the ratio of heat actually used in the greenhouse to the heat supplied from external sources. Heat actually used in the greenhouse is the difference between rate of heat supplied from all sources and rate of heat dissipated into the two sinks, neglecting all other losses. The efficiency is therefore given by

$$
\eta_{r}=1-\left(\dot{Q}_{w}+\dot{Q}_{g}\right) /\left(\dot{Q}_{s}+\dot{Q}_{r}\right)
$$

which, in terms of the dimensionless energy fluxes, becomes

$$
\eta_{r}=1-\left(\varepsilon_{w}+\varepsilon_{g}\right) /\left(\varepsilon_{s}+\varepsilon_{r}\right)
$$


Equations (3)-(12) show that the energy fluxes, thermal efficiency and overall heat transfer coefficient are functions of the dimensionless moduli $R N$ and $\mathcal{K}$ as well as the dimensionless temperatures $\mathscr{T}_{a}, \mathscr{J}_{i}, \mathscr{T}_{e}, \mathscr{J}_{g}, \mathscr{I}_{i n}$ and $\mathscr{T}_{b}$. These dimensionless variables are to be obtained directly or indirectly from experiments described in the next section.

It is noteworthy that the interior and base temperatures $\left(\mathscr{F}_{i n}, \mathscr{J}_{b}\right)$ are to be computed from the arithmetic averages of the temperatures measured at various locations within the greenhouse.

\section{Experimentation}

\subsection{The Model Greenhouse}

A model greenhouse of semi-cylindrical shape was built with fabrene as a membrane on its circumferential periphery and end walls, the membrane being supported longitudinally by three equally spaced $13 \mathrm{~mm}$ rods, which also serve as supports for the thermocouple leads. The greenhouse has a rectangular base of $3.6 \mathrm{~m}$ by $2.6 \mathrm{~m}$, which is insulated with fibreglass (two layers of R20 and one layer of R12) having a total thickness of $38 \mathrm{~cm}$; it is $84 \mathrm{~cm}$ high above the insulation.

A centrifugal blower, with a capacity of $11.2 \mathrm{~m}^{3} \cdot \mathrm{min}^{-1}$ against a head of $711 \mathrm{~mm}$ of water, drives air over a $3 \mathrm{~kW}$ resistance heater to provide hot air for the greenhouse. Both flow rate and temperature of air entering the greenhouse are regulated, respectively, by means of a handoperated butterfly valve in the blower discharge line and a semi-automatic electronic temperature controller connected to the heater.

The experimental setup is fully instrumented to enable automatic monitoring (by means of a data logger) of thirty-eight temperature locations and pressure probes (Fig. 2). Solar intensities and wind speeds and directions are also recorded in collaboration with a University of Calgary weather station situated less than a kilometer from the greenhouse.

\subsection{Experimental Procedure}

The main variables which appear to affect the operation of the greenhouse significantly and which have been considered in this study are:

a) Outside or ambient temperatures;

b) Solar intensity;

c) Temperature of hot air entering the greenhouse

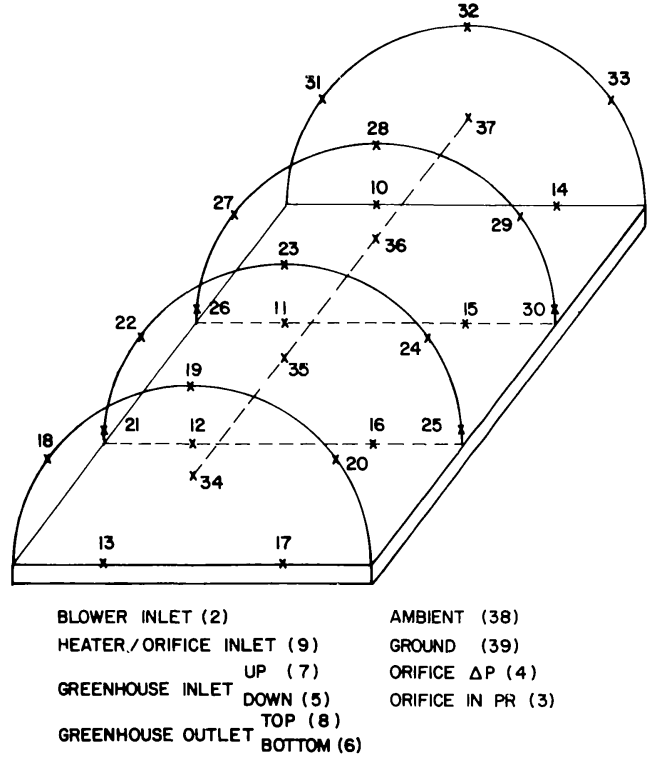

Fig. 2. Thermocouple locations/data logger channels for greenhouse.

and

d) Mass/volumetric flow rate of hot air intake.

The experimental procedure is, therefore, to attempt to suppress some of these important variables while one or two others are allowed to vary. The hot air temperature and mass flow rate are easily controllable while outside conditions, such as ambient temperature and solar intensity, are beyond control. However, by a judicious timing of the experiments, these apparently uncontrollable variables may be found to remain appreciably constant. For example, the solar intensity may be considered to be approximately constant, if the duration of the experiment is short, say fifteen minutes, or zero, if the experiment is performed after sunset.

In view of these realities, two types of experiments were designed: one for very short duration and another one for long period. In the first case, a series of tests were conducted over very short intervals during which the solar intensity and ambient temperature conceivably remained constant while either the hot air flow rate or its temperature was allowed to vary. This set of experiments allowed determination of the effect of varying mass flow rate or hot air temperature.

In the second set of experiments, the hot air flow rate and temperature were kept constant by 
appropriate settings of the butterfly valve and the temperature controller, while both the ambient temperature and the solar intensity were allowed to "run wild", depending on the vagaries of the weather.

Detailed experimental procedures used in this work are outlined in a report of Kessey (1981).

\section{Results}

\subsection{Introduction}

With the aid of the digital computer, the equations derived in Section 2 were used, together with relevant physical data taken from British Standard (B.S. 1042: Part 1: 1704) and Refs. (Holman, 1968; Kern, 1950), to analyse very extensive experimental data collected during the winter months of $1980-81$ in an attempt to determine the performance of the model greenhouse as exemplified by the variation in the following key parameters:

i) the greenhouse interior temperature;

ii) the energy transfer rates, including energy losses;

iii) the overall heat transfer coefficient of the membrane and

iv) the efficiency.

These quantities have been expressed in dimensionless forms as $\mathscr{T}_{i n}, \mathfrak{E}_{s}, \mathfrak{E}_{g}, \mathfrak{E}_{w}$, and $\mathfrak{W}$.

The main objective of this work was to determine the effect of both controlled and uncontrolled variables, such as hot air flow rate and solar energy, on the above quantities. To make the results of this study more generally applicable, these variables have been expressed also in dimensionless form. Hence, the Reynolds Number $(R N)$, Solar Parameter (K), dimensionless inlet Hot Air Temperature $\left(\mathscr{T}_{i}\right)$ and dimensionless Ambient Temperature $\left(\mathscr{T}_{a}\right)$ have been used in lieu of air flow rate, solar energy, hot air temperature and ambient temperature, respectively. The Reynolds Number is a well-known dimensionless modulus characterizing the flow of gases and liquids. However, to the best knowledge of the authors, the Solar Parameter, which characterizes the solar energy input, is a new variable which was found to have a significant influence on the performance of the greenhouse.

\subsection{Energy Distribution}

A typical hourly distribution of the relevant energy rates $\left(\varepsilon_{s}, \varepsilon_{r}, \varepsilon_{w}\right.$ and $\left.\varepsilon_{g}\right)$ is shown in Fig. 3 for an operating period of twenty-four hours at almost constant Reynolds Number $(R N)$ and dimensionless inlet temperature $\left(\mathscr{T}_{i}\right)$. It is noteworthy that ground loss, shown in this figure in a rather "magnified" manner, is less than onehundredth of the other energy rates due to the insulation on the base used to minimize this loss.

One observes from Fig. 3 that the rates of energy loss $\left(\varepsilon_{w}\right.$ and $\left.\varepsilon_{g}\right)$ remain relatively constant between sunset and sunrise but rise or fall during sunshine hours with increasing or decreasing solar input. Consequently, the energy losses are at their peak almost simultaneously with the peaking of solar intensities or solar input, which occurs around 13:00 hours.

The above-mentioned trend is to be expected for the following reason. When hot air heat input remains approximately constant due to constant Reynolds Number and hot air inlet temperature, solar energy is the only variable energy source to bring about variations in the performance characteristics of the greenhouse. Hence, increasing solar energy input during the afternoon hours leads to an increase in greenhouse average interior and base temperatures and, consequently, an increase in the temperature difference between the greenhouse interior/base and the outside/ground temperatures. Therefore, surface and ground losses rise or fall with rising or decreasing solar energy.

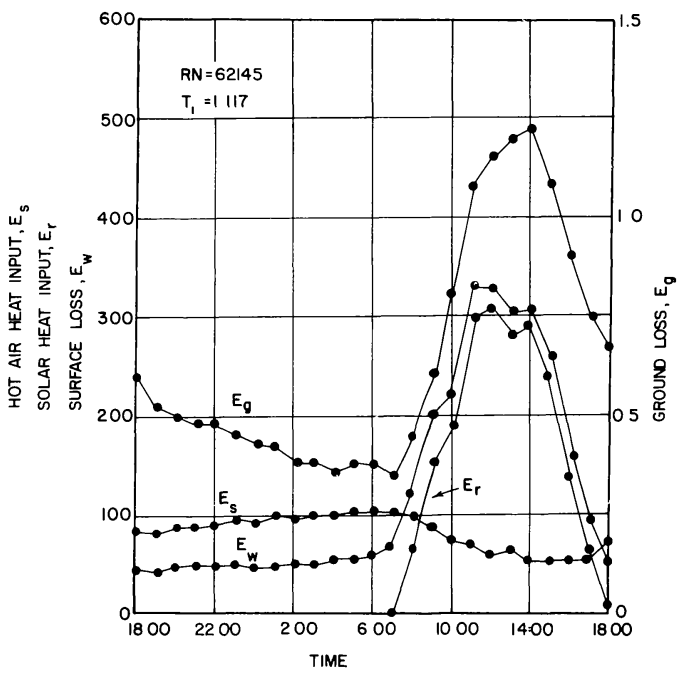

Fig. 3. Hourly energy transfer rates. 
The distribution of the energy transfer rates is also shown in Fig. 4 as functions of the Reynolds Number. The rate of heat loss through the base of the greenhouse has not been shown in this figure since it is not an explicit function of the Reynolds Number. As explained in the next section, the rise of the energy rates with increasing $R N$, notably the membrane heat loss, as depicted in this figure, is to be expected.

It is observed from Fig. 4 that the membrane heat loss is much higher than either the hot air heat input or solar energy input, for low $R N$, even though it is less than the combined total of these two energy sources. However, membrane losses rise less steeply than hot air heat input, which indicates that it may be possible to minimize these excessive membrane losses with high Reynolds Numbers or flow rates.

\subsection{Effects of the Dimensionless Moduli}

In this paper, the effects of only the two dimensionless moduli $R N$ and $\mathscr{T}_{i}$, which directly relate to hot air heat input, are discussed in detail. The other two important parameters, namely, the Solar Parameter and Ambient/Environmental Temperature, will be fully dealt with in subsequent papers.

a) The Reynolds Number $(R N)$

The dependence of the various quantities on the Reynolds Number (related to air flow through the inlet pipe of the greenhouse) is depicted in Figs. 4 -8 indicating that, except for the dimensionless solar energy, all above-mentioned variables, $\mathscr{J}_{i n}$, $\varepsilon_{s}, \varepsilon_{w}, \mathscr{k}$, and $\eta$, increase with increasing Reynolds Number for air being blown into the greenhouse at almost constant $\mathcal{K}, \mathscr{T}_{i}$ and $\mathscr{T}_{a}$.

These trends are as expected since increasing Reynolds Number, or hot air flow rate, presumably leads to a better mixing of the greenhouse cold air with the incoming hot air and to a more effective use of the hot air in raising the interior temperature of the greenhouse. With increased interior temperatures, the Surface Loss, $\left(\varepsilon_{w}\right)$, increases with a corresponding increase in the overall heat-transfer coefficient ( $(6)$ ).

Consistent with this postulate, namely, that effective use of the hot air results from good mixing of the air in the greenhouse, is the fact that the efficiency of the greenhouse as an "energy user" increases with increasing Reynolds Number, notwithstanding the increase in the membrane losses.

\section{b) Hot Air Temperature $\left(\mathscr{T}_{i}\right)$}

The effect of Hot Air Temperature on the performance of the greenhouse is especially noticeable in Figs. 5 and 8. These figures show an increase in average greenhouse interior temperature

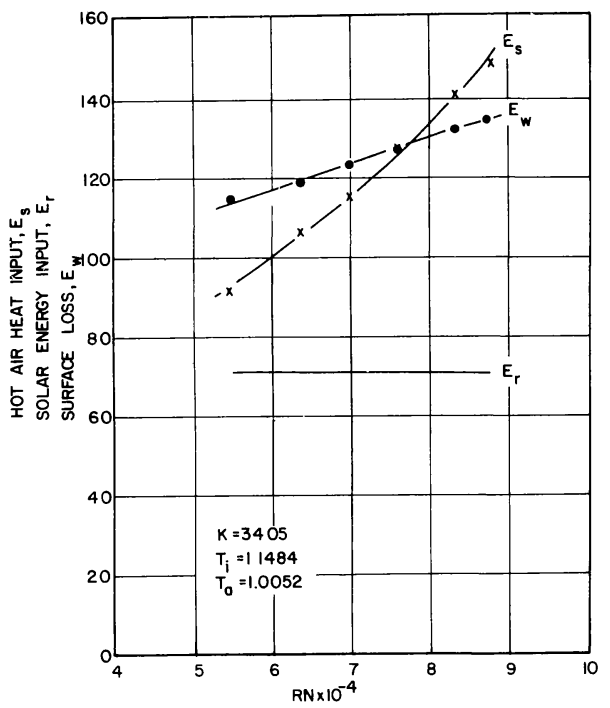

Fig. 4. Variations of energy rates with Reynolds Number.

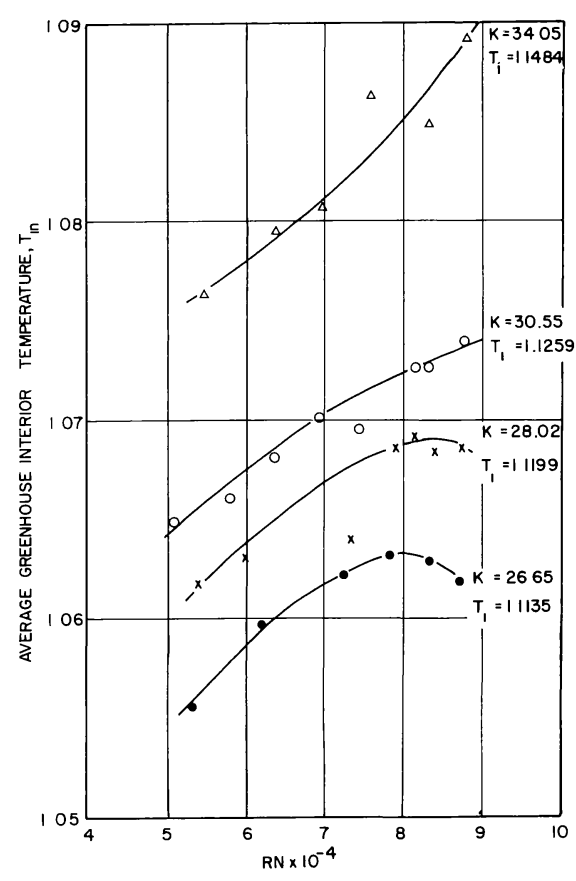

Fig. 5. Variations of interior temperature with Reynolds Number. 


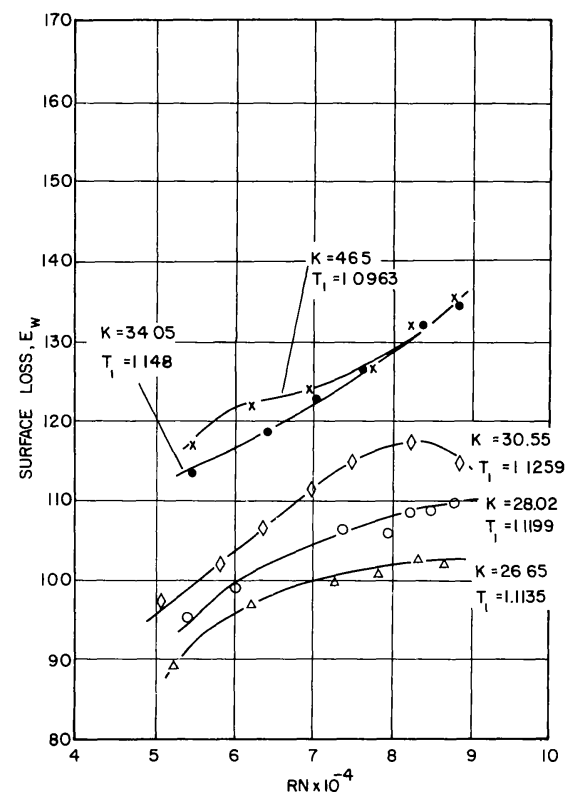

Fig. 6. Variations of surface loss with Reynolds Number.

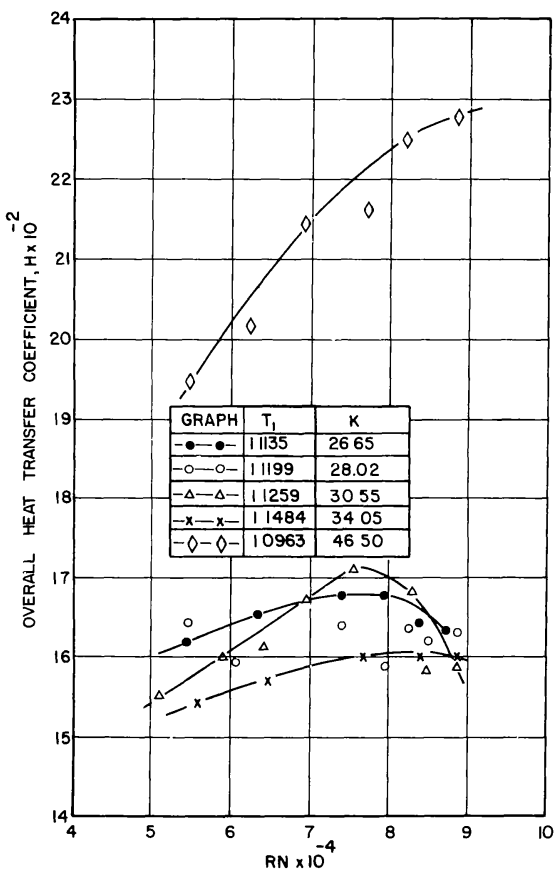

Fig. 7. Variations of overall heat transfer coefficient with Reynolds Number.

and efficiency with increasing inlet temperature $\mathscr{T}_{i}$.

An increase in Hot Air T'emperature brings about a high increase in the interior temperature and surface loss but rather low increase in the

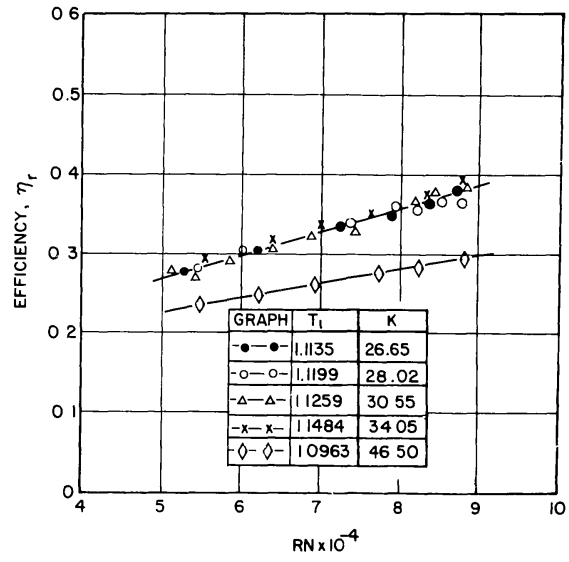

Fig. 8. Variations of efficiency with Reynolds Number.

overall heat transfer coefficient as well as thermal efficiency. This is as expected. For, it appears that the internal heat exchange within the greenhouse between the incoming moving, warm air and the relatively quiescent, cold inside air is considerably enhanced when the "fresh" air is very warm. Consequently, there is greater improvement in the utilization of hot air energy as characterized by its temperature $\mathscr{T}_{i}$. Hence the efficiency increases.

However, the greenhouse interior temperature never attains the temperature of the entering hot air. This is fortuitous. It means that a slightly greater inlet Hot Air Temperature is permissible than that which is desirable for optimum growth of the vegetation in the greenhouse. By provision of a suitable inlet diffuser, the incoming hot air is diffused into the inside air without raising the local temperature anywhere in the interior to a "harmful" level. How high the temperature of the intake hot air should and can be is yet to be determined based on vegetation requirements.

\section{Conclusions}

Some of the major conclusions of this work, all of which have been discussed in Section 4, are summarized below for conciseness.

(1) The performance of the greenhouse, as characterized by its energy transfer rates and thermal efficiency, depends more on two dimensionless parameters (the Reynolds Number and the Solar Parameter) than on the temperature 
of the intake hot air. The Reynolds Number and the Solar Parameter represent, respectively, the air flow rate through the inlet duct and the solar energy input.

(2) The surface or membrane heat loss and, consequently, the overall heat transfer coefficient increases significantly with increasing Reynolds Number.

(3) Membrane heat losses are very high and may be of the same magnitude as either the hot air heat input or the solar energy input.

(4) The average interior temperature of the greenhouse increases significantly with increasing intake hot air temperature and the Reynolds Number. However, as in the case of the energy transfer rates, the Reynolds Number appears to have a greater effect on the interior temperature than the temperature of the inlet hot air. In fact, admission of hot air at an exceedingly high temperature does not necessarily raise the interior temperature of the greenhouse beyond limits normally required or acceptable for plant growth, as long as a proper air distribution system is provided to circulate the air inside the greenhouse.

\section{Nomenclature}

\section{Italic Letters}

Area

$C_{p} \quad$ Specific heat at constant pressure

$D \quad$ Diameter of greenhouse

$d \quad$ Diameter of blower discharge duct

$h \quad$ Convective heat transfer coefficient

I Intensity of radiation

$k \quad$ Thermal conductivity

$L \quad$ Length of greenhouse

$l \quad$ Thickness of insulation

$\dot{m} \quad$ Mass flow rate $\left(\mathrm{kg} \cdot \mathrm{sec}^{-1}\right)$

$\dot{Q} \quad$ Rate of heat or energy transfer (W)

$T \quad$ Absolute temperature

$T_{0} \quad 273.2^{\circ} \mathrm{K}$, reference absolute temperature

$t \quad$ Ordinary temperature

$U \quad$ Overall heat transfer coefficient

$u \quad$ Local velocity of air

\section{Greek Symbols}

$\begin{array}{ll}\rho & \text { Air density } \\ \mu & \text { Absolute viscosity }\end{array}$
$\tau \quad$ Transmissivity
$\eta_{r} \quad$ Efficiency involving solar energy

\section{Dimensionless Moduli}

$\begin{array}{ll}\mathcal{E}=\dot{Q} / L k_{a} T_{o}=E & \begin{array}{l}\text { Dimensionless energy flow } \\ \text { rate }\end{array} \\ \mathscr{f}=U A_{w} / k_{a} L=H & \begin{array}{l}\text { Dimensionless overall heat } \\ \text { transfer coefficient }\end{array} \\ \mathcal{K}=\tau I_{t} D / k_{a} T_{o}=K & \text { Solar parameter } \\ P_{r}=C_{p} \mu / k_{a} & \text { Prandtl Number } \\ R N=\rho u d / \mu & \text { Reynolds Number } \\ \mathcal{T}=T / T_{o} & \text { Dimensionless temperature }\end{array}$

\section{Subscripts}

a Ambient or outside temperature

$b \quad$ Base

$\boldsymbol{e} \quad$ Exit/outlet

$g \quad$ Ground

$i \quad$ Inlet or insulation

in Interior

o Reference/datum

$r \quad$ Solar radiation

$s \quad$ Supply air

$t \quad$ Total

$w \quad$ Membrane wall

\section{References}

1. Annufrier, L. N. and Pozin, G.M., 1966: Heat balance of hothouses and optical properties of transparent surfaces. Gelioteknika, 2(5), 19-25.

2. Brinkworth, B. J., 1972: Solar energy for man. John Wiley \& Sons, New York.

3. Businger, J. A., 1963: The glasshouse climate. In Physics of Plant Environment (ed. W. R. van Wijk). North-Holland Publishing Co., Amsterdam, 277-318.

4. Edwards, R. I. and Lake, J. V., 1967: The transmission of solar radiation in a small eastwest glasshouse glazed with diffusing glass. J. agric. Engng Res., 12(2), 192-201.

5. Glockner, P. G. and Malcolm, D. J., 1980: Utilization of waste energy in greenhousing and agriculture. Dept. of Mech. Engg. Res., 155, The University of Calgary, Canada.

6. Holman, J. P., 1968: Heat Transfer. McGrawHill Company, New York.

7. Horiguchi, I., 1978: The variation of heating load coefficient for a greenhouse and overall heat-transfer coefficient through plastic film. J. Agric. Meteorol., Tokyo, 33, 175-181. 
8. Iwakiri, S. and Uchijima, Z., 1971: Temperature regime and heat transfer in a glasshouse at the day time. J. Agric. Meteorol., Tokyo, 26, 197-207.

9. Kern, D. Q., 1950: Process Heat Transfer. McGraw-Hill Company, New York.

10. Kessey, K. O., 1981: Experimental investigation of energy transfers including solar energy in the inflatable greenhouse. July, 1981.

11. Kimball, B. A., 1973: Simulation of the energy balance of a greenhouse. Agric. Meteorol., 11, 243-260.

12. Pozin, G. M., 1971: Solution of the system of heat balance equations for hothouses in the unsteady regime. Gelioteknika, 7(2), 47-55.

13. Seginer, I. and Levav, N., 1971: Models as tools in greenhouse climate design. TechnionIsrael Institute of Technology, Agricultural Engineering Faculty, Haifa, Israel. 80 pp.
14. Selcuk, M. K., 1970: Use of digital computers for the heat and mass transfer analyses of controlled environment greenhouses. Environmental Research Laboratory, University of Arizona, Tuscon, Arizona.

15. Snook, C. W. and J. D. Tarasuk, 1975: Heat transfer from inflatable structures. $A S M E$ Publication 75-WA/HT-97.

16. Takakura, T., Jordan, K. A. and Boyd, L. L., 1969: Dynamic simulation of plant growth and environment in the greenhouse. Winter Meeting of the American Society of Agricultural Engineers, Chicago, Ill., 69-942, 57 pp.

17. Takami, S. and Uchijima, Z., 1977: A model of the greenhouse with a storage-type heat exchanger and its verification. J. Agric. Meteorol., Tokyo, 33, 155-166.

18. Woode, R. W., 1909: Note on the theory of the greenhouse. Phil. Mag., 1, 319.

\title{
空気吹込型温室内のエネルギー輸送 に関する実験的研究
}

\author{
ケィ・オー・ケッセイ・ビー・ジー・グロックナー \\ （カルガリー大学機械工学部）
}

\section{要約}

\footnotetext{
透明プラスチックで被覆した植栽のない模型温室を様

には $10 \%$ 程度と低くなった。

々な条件で運転し，熱フラックスの相対的な大きさを検

吹き込んだ温風の質量流量や温室内への透過日射量を

討した。それらは, 温風や太陽からの熱入力, 表面や地

面からの熱損およびその効率である。

被覆面加の熱損失は入力熱量に吭敵し, 一定の運転

条件下では一方の入力熱量よりあ大きいととがあった。 特徵付けるレイノルズ数と新しい太陽パラメータは，そ れぞれ温室の性能に重要な影響を及ぼした。とくに被覆 面からの熱損失が，レイノルズ数の増加と太陽パラメー タの上昇に伴っで著しく増大することが観測された。
} 